Fifth International Conference on Sustainable Construction Materials and

Technologies. http://www.claisse.info/Proceedings.htm

\title{
REACTIVITY OF MODIFIED IRON SILICATE SLAG AS SUSTAINABLE ALTERNATIVE BINDER
}

Pithchai Pandian Sivakumar ${ }^{1,2,3}$, Elke Gruyaert ${ }^{2}$, Nele De Belie ${ }^{1}$, Stijn Matthys ${ }^{1}$

${ }^{1}$ Magnel Laboratory for Concrete Research, Department of Structural Engineering, Ghent University, Tech Lane Ghent Science Park, Campus A, Technologiepark 904, BE-9052 Zwijnaarde, Belgium.

${ }^{2}$ KU Leuven, Department of Civil Engineering, Technology Cluster Construction, Structural Mechanics and Building Materials, Gebroeders De Smetstraat 1, BE-9000 Ghent, Belgium

${ }^{3}$ SIM vzw, Technologiepark 935, BE-9052 Zwijnaarde, Belgium

pithchaipandian.sivakumar@ugent.be,elke.gruyaert@kuleuven.be, nele.debelie@ugent.be, stijn.matthys@ugent.be.

\section{ABSTRACT}

A possible solution to decrease the $\mathrm{CO}_{2}$ footprint caused by the cement industry and to enhance the transition to circular economy is to use slags as Supplementary Cementitious Materials (SCM). The study presented here focuses on valorizing and investigating the reactivity and mechanical properties of blended binder systems combining Modified Iron Silicate (MFS) slag and Ordinary Portland Cement (OPC). MFS slag is a fumed by-product synthesized during the production of Copper $(\mathrm{Cu})$ metal. This slag can be used as possible alternative SCM due to its pozzolanic behaviour. To study the replacement level in relation to reactivity and strength development, replacement levels of 15, 30 and $50 \mathrm{wt} \%$ of MFS-slag in ordinary portland cement are analyzed. The work can be divided into two categories: 1) assessing the reactivity through thermogravimetric analysis (TGA) and 2) evaluating the compressive strength (as a function of time) of mortar with MFS-slag after 2, 7, 28 and 90 days. TGA at 7, 15, 28 and 90 days allows to determine the reduction of portlandite content which gives an indication on the pozzolanic reactivity. Reactivity of MFS-slag blended systems is also determined relative to inert filler blended systems to discern between the reactive behavior of the MFS-slag and the filler effect.

Keywords: Supplementary cementitious materials, modified iron silicate, ordinary portland cement, thermogravimetric analysis.

\section{INTRODUCTION}

As the cement industry is one of the main contributors to the global $\mathrm{CO}_{2}$ footprint, a possible solution has to be found to decrease $\mathrm{CO}_{2}$ emissions (Worrell et al., 2001; 
Benhelal et al., 2013; US Geological Survey \& Orienteering S, 2017). One of these solutions can be to use Supplementary Cementitious Materials (SCM) such as slags. Usage of slags in concrete decreases the need for Portland clinker production and so the industrial $\mathrm{CO}_{2}$ footprint (Scrivener and Kirkpatrick, 2008). Pyro-metallurgical processes involving oxidation and reduction of Copper $(\mathrm{Cu})$ ore or scrap to synthesize $\mathrm{Cu}$ metal also produce slags as by-product (Schlesinger et al., 2011). Cu slag's chemical composition varies depending on the initial $\mathrm{Cu}$ source and the processing condition. However, $\mathrm{Cu}$ slags are mainly composed of $\mathrm{SiO}_{2}, \mathrm{FeO}$, and $\mathrm{CaO}$, similarly to other natural/artificial pozzolanic materials (Piatak, Parsons and Seal, 2015).

Several types of industrial by-products such as blast furnace slag or fly ash are widely used in the cement industry as SCM (Lothenbach, Scrivener and Hooton, 2011). These by-products are rich in an amorphous phase (typically $>90 \mathrm{wt} \%$ ) containing oxides of $\mathrm{Si}, \mathrm{Ca}, \mathrm{Al}$ and $\mathrm{Fe}$ and are latent hydraulic or pozzolanic. When for instance blast furnace slags are added together with ordinary portland cement (OPC) in a mortar or concrete mix, the amorphous phase reacts with the alkaline pore solution (enriched in $\mathrm{CH})$ precipitating hydrates of calcium silicates $(\mathrm{C}-\mathrm{S}-\mathrm{H})$. These slags can be used as SCM without modification and can satisfy the requirements of demanding construction applications. In terms of literature, a wide range of publications has proven that usage of amorphous materials such as metakolin and blast furnace slags in combination with OPC can enhance the mechanical properties and durability of concrete (Werner et al., 1987; Hooton, 2000; Siddique and Klaus, 2009; Juenger et al., 2011).

Literature has already revealed that $\mathrm{Cu}$ slags can be used as a SCM without compromising the mechanical properties of OPC concrete. In the work of Moura et al (Moura, Gonçalves and Lima, 2007), Cu slags were used as SCM and the effect on strength and durability was examined. It was confirmed that replacement of OPC with 20 wt.\% Cu slags increased the compressive strength at late ages. Moura et al also stated that use of $\mathrm{Cu}$ slag in concrete could improve the durability.

Edwin et al (Edwin, Gruyaert and De Belie, 2017) assessed the reactivity of the $\mathrm{Cu}$ slag by incorporating it in a "Reactive Powder Concrete" (RPC) from 0 to $20 \mathrm{wt} \%$. Findings published showed that the strength of the RPC with $20 \mathrm{wt} . \% \mathrm{Cu}$ slags was better than the reference mixture at 28 days. However, the pozzolanic reactivity determined by the Chapelle test was found to be low. In the work of Edwin et al (Edwin et al., 2016), the reactivity and effect of Cu slag as SCM in ultra-high performance mortar was assessed by isothermal calorimetry, strength activity index, Chapelle test and Frattini test. The final conclusions were that 1 ) addition of $\mathrm{Cu}$ slags slows down the hydration/heat flow of the cement paste and 2) rate of pozzolanic activity of the $\mathrm{Cu}$ slag depends on temperature, curing age and particle size. Tixier et al (Tixier, Devaguptapu and Mobasher, 1997) studied the effect of $\mathrm{Cu}$ slag on the hydration and mechanical properties of cementitious mixtures. $\mathrm{Cu}$ slag was blended with lime to test its pozzolanic behavior. XRD/TGA (X-ray diffraction / thermogravimetric analysis)of 
the $\mathrm{Cu}$ slag/lime samples indicates a decrease in the available $\mathrm{CH}$ content which is an indication of pozzolanic reaction. Mechanical properties of the concrete incorporating SCM showed a significant increase in the compressive strength. This increase in the compressive strength is due to the combination of filler and pozzolanic effect.

In this paper, reactivity and mechanical properties of paste/mortar made with a binder consisting of processed $\mathrm{Cu}$ slag, more correctly designated as "Modified Ferro silicate (MFS) slags", as SCM along with OPC were studied. These MFS slags are similar Cu slags as investigated by Edwin et al(Edwin et al., 2016), however an additional fuming process of this slag was carried out to turn it from a by-product into a mineral. In order to enhance the transition towards sustainability, the goal is to use these clean pozzolanic MFS slags as SCM in combination with OPC. Reactivity and hydration products of the SCM paste were analyzed using TGA. Mortar with MFS slags with replacement levels of 15,30 and 50 wt\% of MFS-slag in OPC were prepared to evaluate the compressive strength.

\section{EXPERIMENTAL PROCEDURE}

Patented Modified Ferro Silicate (MFS) slag (WO 2016156394 A1) is used as the raw material along with reference materials such as OPC (CEM I $52.5 \mathrm{~N}$ ) and inert filler (quartz flour type M10). Chemical and mineralogical characterization of the raw materials were performed through X-ray fluorescence (XRF) and XRD. Specific surface area and particle size distribution of the raw materials were assessed by the Blaine method according to EN 196-6 and laser diffraction analysis respectively. Binders were prepared containing replacement levels of 15, 30 and $50 \mathrm{wt} \%$ of MFSslag in OPC (specimens indicated with letter $\mathrm{M}$ ), along with controls containing the same replacement percentages of inert filler (specimens indicated with letter $\mathrm{R}$ ), and an OPC reference (Table 1). The water/solid ratio was kept constant at 0.5 for all pastes. Reactivity of the binders in the hydrated pastes was assessed after 7, 15, 28 and 90 days through TGA. Hydration of the pastes at their respective ages was stopped by placing the crushed paste in isopropanol for $4 \mathrm{~h}$ and filtering using a $2.7 \mu \mathrm{m}$ pore size filter. Dry filtered pastes were stored in a vacuum chamber to avoid further hydration. TGA was performed to quantitatively evaluate the presence of $\mathrm{CH}$, by means of a TA instrument SDT2960 (TG-DSC). The experiment was carried out in an Aluminium (Al) crucible, with a heating rate of $10{ }^{\circ} \mathrm{C} / \mathrm{min}$ in a $\mathrm{N}_{2}$ atmosphere. Thermal analysis software (Proteus analysis software was used to measure the quantitative presence of $\mathrm{CH}$ in all pastes. Single measurements were performed for a series and no repetitions were carried out. Compressive strength was assessed on OPC, 15M, 30M and 50M mortars (at time of preparation of this paper the test results on the $15 \mathrm{R}, 30 \mathrm{R}$ and $50 \mathrm{R}$ specimens were not yet fully available), prepared as per EN 196-1 and cured at $20 \pm 1$ ${ }^{\circ} \mathrm{C}$ and $95 \%$ relative humidity for $24 \mathrm{~h}$. Later the mortars were demolded and stored in a curing chamber at $20 \pm 1{ }^{\circ} \mathrm{C}$ and $95 \%$ relative humidity until the compressive strength were performed. 
Table 1. Binder composition in wt.\%

\begin{tabular}{|l|l|l|l|}
\hline Mortar/Paste & OPC & MFS & M10 \\
\hline OPC & 100 & 0 & 0 \\
\hline $15 \mathrm{M}$ & 85 & 15 & 0 \\
\hline $30 \mathrm{M}$ & 70 & 30 & 0 \\
\hline $50 \mathrm{M}$ & 50 & 50 & 0 \\
\hline $15 \mathrm{R}$ & 85 & 0 & 15 \\
\hline $30 \mathrm{R}$ & 70 & 0 & 30 \\
\hline $50 \mathrm{R}$ & 50 & 0 & 50 \\
\hline
\end{tabular}

\section{RESULTS AND DISCUSSION}

\section{Characterization of Starting Materials}

Tables 2 and 3 provide the chemical and mineralogical composition of the MFS slag. MFS slags mainly possess oxides of $\mathrm{Fe}^{2+}$ or $\mathrm{Fe}^{3+}$, $\mathrm{Si}$ and $\mathrm{Al}$. Mineralogical analysis through X-ray diffraction shows more than $90 \mathrm{wt} \%$ of MFS slag as amorphous phases with presence of minor content crystalline phases such as spinel and metallic iron.

Table 2. Chemical composition of the MFS slags

\begin{tabular}{|l|l|l|l|l|l|}
\hline Oxides & $\mathrm{FeO} / \mathrm{Fe}_{2} \mathrm{O}_{3}$ & $\mathrm{SiO}_{2}$ & $\mathrm{Al}_{2} \mathrm{O}_{3}$ & $\mathrm{CaO}$ & Others \\
\hline wt.\% & 40.9 & 32.3 & 11.0 & 3.9 & 11.9 \\
\hline
\end{tabular}

Table 3. Mineralogy of the MFS slag

\begin{tabular}{|l|l|}
\hline Phases & $\mathrm{Wt} \%$ \\
\hline Amorphous & $92.7 \pm 0.8$ \\
\hline Spinel & $6.7 \pm 0.6$ \\
\hline Iron & $0.7 \pm 0.2$ \\
\hline
\end{tabular}

Table 4 provides the specific surface area and particle size distribution of the starting materials. MFS slags were milled in an attritor grinding process for a specific time to achieve a similar particle size distribution and specific surface area as the OPC. Also, the inert filler material was selected to have similar characteristics.

Table 4. Particle size distribution and Blaine surface of the starting materials

\begin{tabular}{|l|l|l|l|l|}
\hline \multirow{2}{*}{$\begin{array}{l}\text { Starting } \\
\text { materials }\end{array}$} & \multicolumn{3}{|c|}{ Particle size } & $\begin{array}{l}\text { Specific } \\
\text { surface area } \\
\left(\mathrm{cm}^{2} / \mathrm{g}\right)\end{array}$ \\
\cline { 2 - 5 } & $\mathrm{d}_{10}(\mu \mathrm{m})$ & $\mathrm{d}_{50}(\mu \mathrm{m})$ & $\mathrm{d}_{90}(\mu \mathrm{m})$ & $4300 \pm 235$ \\
\hline OPC & 1.316 & 8.912 & 30.192 & $4800 \pm 250$ \\
\hline MFS & 2.928 & 12.087 & 45.514 & 3800 \\
\hline M10 & 3.704 & 10.963 & 40.276 & $4000 \pm 225$ \\
\hline
\end{tabular}




\section{Reactivity Assessment Through Thermogravimetric Analysis}

Mass as a function of temperature as well as its derivative (rate in mass change) of the hydrated pastes after 90 days is shown in Figure 1. cement is usually composed of mineralogical phases such as $\mathrm{C}_{3} \mathrm{~S}, \mathrm{C}_{2} \mathrm{~S}, \mathrm{C}_{3} \mathrm{~A}$ and $\mathrm{C}_{4} \mathrm{AF}$ which reacts with $\mathrm{H}_{2} \mathrm{O}$ to produce hydration product. The important hydration reaction product of the cement paste are C-S-H and CH (Sha, O'Neill and Guo, 1999). Wide range of authors have already studied and described in detail the thermal decomposition of the hydrated cement paste. Major decomposition of the hydrated pastes takes place between 30 to $105^{\circ} \mathrm{C}, 110$ to $170^{\circ} \mathrm{C}, 180$ to $300^{\circ} \mathrm{C}, 450$ to $550^{\circ} \mathrm{C}$ and 700 to $900^{\circ} \mathrm{C}$.

1) The first region between the temperature range 30 to $105{ }^{\circ} \mathrm{C}$ is mainly due to the dehydration of evaporable water (Alarcon-Ruiz et al., 2005).

2) The region in the temperature range between 110 to $170^{\circ} \mathrm{C}$ is due to the decomposition of ${\mathrm{C} \$ \mathrm{H}_{2}}_{2}, \mathrm{AFt}, \mathrm{SO}_{4}{ }^{2-}-\mathrm{AFm}, \mathrm{CO}_{3}{ }^{2-}-\mathrm{AFm}$ (as per cement notation) (Zhou and Glasser, 2001; Alonso and Fernandez, 2004).

3) The loss of bound water from the dehydration reactions from $\mathrm{C}-\mathrm{S}-\mathrm{H}$ takes places in the temperature range of 180 to $300^{\circ} \mathrm{C}$ (Nonnet, Lequeux and Boch, 1999; Zhou and Glasser, 2001; Alarcon-Ruiz et al., 2005; Pane and Hansen, 2005).

4) Mass loss in the temperature region between 450 to $550{ }^{\circ} \mathrm{C}$ corresponds to the dehydration of $\mathrm{CH}$ (Zhang and Ye, 2012; Deboucha et al., 2017).

5) The final decomposition occurs due to the decarbonation of carbonate phases in the temperature range between 700 to $900{ }^{\circ} \mathrm{C}$ (Grattan-Bellew, 1996; Deboucha et al., 2017).

$$
C H(\%)=m_{\text {loss } 450-550{ }^{\circ} \mathrm{C}} * \frac{M W_{C H}}{M W_{H 2 O}}
$$

The percentage of $\mathrm{CH}$ can be calculated by the formula 1 where the parameter $\mathrm{m}_{\text {loss }} 450$ $550^{\circ} \mathrm{C}$ is included for considering the dehydration of $\mathrm{CH}$ and the mass conversion factor of $\mathrm{H}_{2} \mathrm{O}$ to $\mathrm{CH}$ can be calculated by the ratio of molecular weight (MW) of $\mathrm{CH}$ and $\mathrm{H}_{2} \mathrm{O}$ (Chen et al., 2007). To be more accurate, for each specific paste, the $450-550{ }^{\circ} \mathrm{C}$ boundaries were slightly adjusted given the exact location of the $\mathrm{CH}$ region in Figure 1. However, the mass loss due to $\mathrm{CH}$ decomposition generally lays between 450 and $550^{\circ} \mathrm{C}$ which was determined by tangent method.

Figure 2 shows the presence of $\mathrm{CH}$ in the hydrated SCM paste at the different ages of 7, 15, 28 and 90 days with comparison to the reference of paste made from inert filler and OPC. It can be clearly seen that all SCM pastes synthesized with the MFS slag show presence of less $\mathrm{CH}$ compared to the paste made from inert filler and OPC, especially at 28 and 90 days. This indicates that $\mathrm{CH}$ formed as the reaction product during OPC hydration is dissolved in the pore solution and consumed by the MFS slag through pozzolanic reaction. 
a)

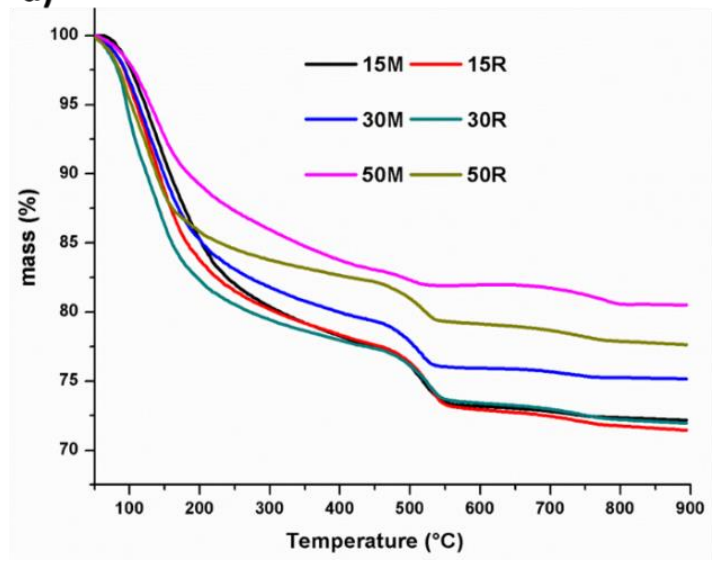

b)

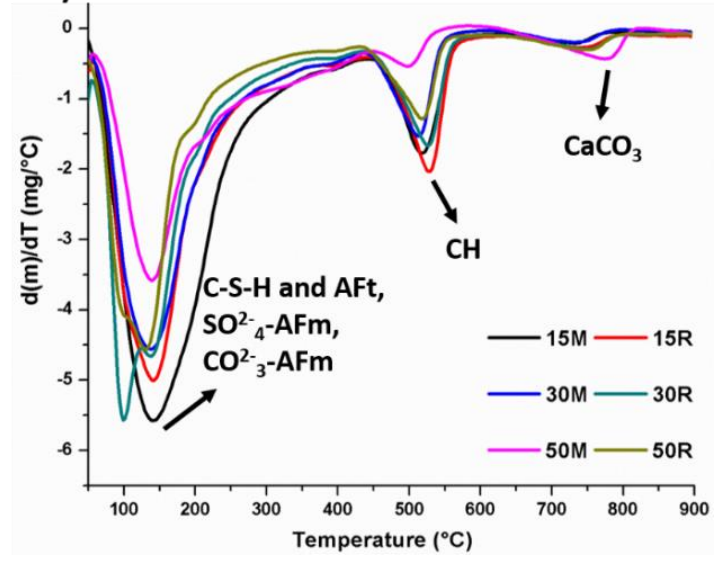

Figure 1. TGA curve of the powdered paste after 90 days: a) mass loss (\%) vs temperature $\left({ }^{\circ} \mathrm{C}\right)$, and $\left.\mathrm{b}\right)$ rate of change of mass $\left(\mathrm{mg} /{ }^{\circ} \mathrm{C}\right)$ vs temperature $\left({ }^{\circ} \mathrm{C}\right)$

a)

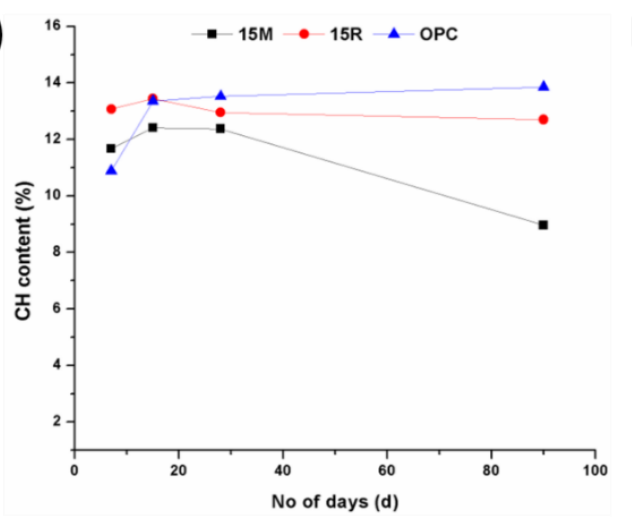

b)

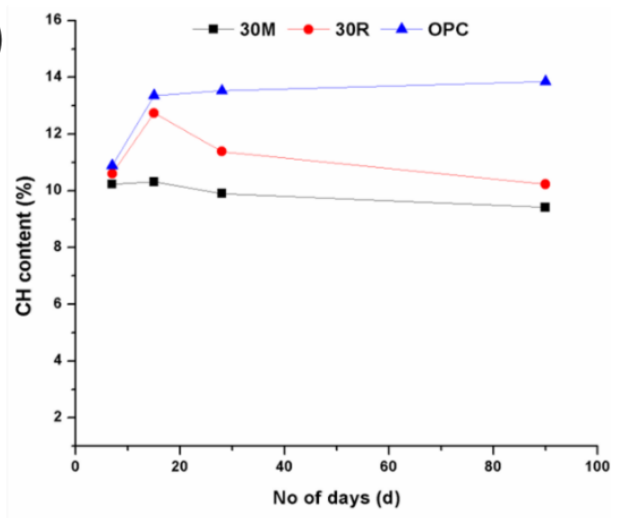

c)

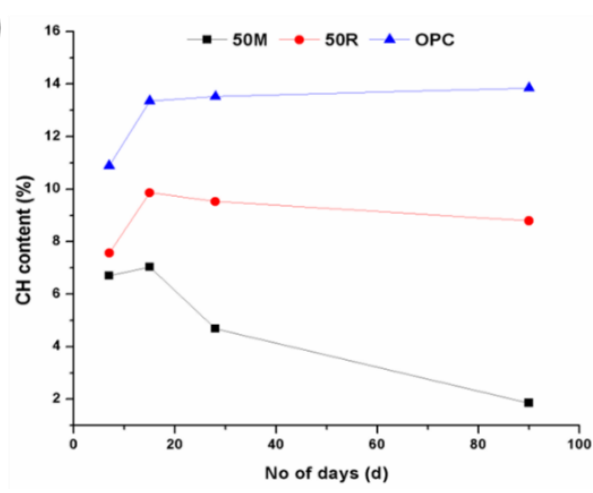

Figure 2. Calculated $\mathrm{CH}$ content in wt.\% with $\mathrm{OPC}$ as reference a) $15 \mathrm{M}$ vs $15 \mathrm{R}$, b) $30 \mathrm{M}$ vs $30 \mathrm{R}$ and c) $50 \mathrm{M}$ vs $50 \mathrm{R}$ 
However, 7 days TGA analysis of MFS slag and inert filler paste showed presence of high $\mathrm{CH}$ content compared to the OPC paste which is possibly due to the enhancement of OPC hydration by filler effect, thus producing more $\mathrm{CH}$ (Cordeiro et al., 2008). Moreover slight decrease in the trend of $\mathrm{CH}$ content between 28 days and 90 days of the inert filler paste especially $30 \mathrm{R}$ and $50 \mathrm{R}$ indicates that quartz filler though assumed inert, consumes a small amount of $\mathrm{CH}$. A similar observation has been made and discussed in the literature (Cyr, Lawrence and Ringot, 2005; Moesgaard et al., 2011; Deschner et al., 2012).

\section{Strength Development of SCM Mortars Synthesized From MFS Slags}

Evaluation of the compressive strength was carried out among all MFS mortars, and also compared to $85 \%, 70 \%$ and $50 \%$ of the OPC compressive strength as nominal reference values (Figure 4). Note that this comparison is not completely fair, given the difference in underlying hydration mechanism, but allows to observe the trends better. The 2 days strength of the synthesized SCM mortars such as $15 \mathrm{M}$ and $50 \mathrm{M}$ was lower than the respective reference values taking into account the dilution of OPC, whereas the 2 days strength of $30 \mathrm{M}$ was similar to the reference value. This shows that the replacement with MFS slags leads generally into a decrease in the 2 days compressive strength, even surpassing the strength reduction expected from the decrease in OPC content. This might be attributed to the MFS slag delaying the OPC hydration and the MFS slag reaction itself requiring more time.

At 7 days, the observed trend at 2 days, is turned around with higher strengths up to 55 $\mathrm{MPa}$ and $40 \mathrm{MPa}$ for respectively $15 \mathrm{M}$ and $30 \mathrm{M}$. At 28 and 90 days, all synthesized MFS mortars showed high compressive strength compared to their OPC content. Strength development of the SCM mortar synthesized from MFS slags showed slow increase from 2 days to 7 days and high increase in the period from 7 to 90 days compared to the reference value. This kind of strength development is due to the presence of MFS slag itself and linked to the possible mechanism of slow dissolution of amorphous silica in the alkaline pore solution (Barret, Ménétrier and Cottin, 1977) and the formation of strength providing phases such as C-S-H and C-A-S-H which will be further investigated. 

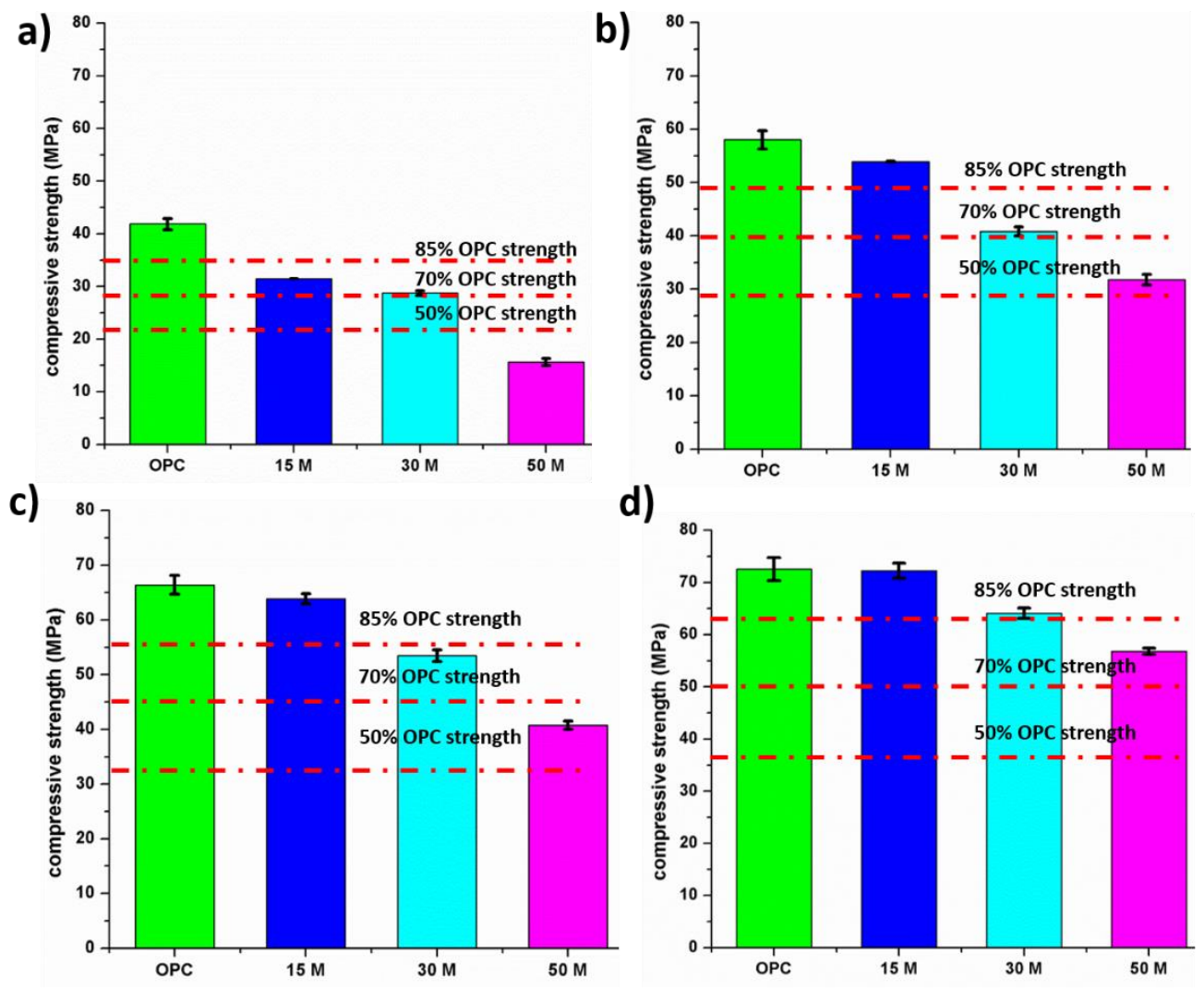

Figure 3. Mean compressive strength of synthesized mortars a) 2 days, b) 7 days and c) 28 days d) 90 days

\section{CONCLUSION}

The present work proved that MFS slag can be a promising alternative pozzolanic material. MFS slag, used as a substitute for OPC, contributes to the mechanical properties at later ages (starting to be observed at 7 days and strongly observed at 28 days). Assessment through TGA based on the relative reduction in $\mathrm{CH}$ content provided suitable information on the MFS slag reactivity.

In particular the following points can be emphasized

1) TGA analysis predicted presence of less $\mathrm{CH}$ concentration among all MFS slag binders compared to the inert filler and OPC binder after 28- and 90-days suggesting $\mathrm{CH}$ was consumed through pozzolanic reaction.

2) Due to the existence of $\mathrm{SiO}_{2}$ rich amorphous phase in MFS slags, strength development showed an increase above the expected strength considering the reduction in OPC content at the age of 28 days.

3) The observed strength increases can possibly be attributed to a combination of pozzolanic reaction and filler effect which is under further investigation. 


\section{ACKNOWLEDGE}

The work has been performed in the Magnel Laboratory for Concrete Research, Department of Structural Engineering, Ghent University and financed by the SIM MARES program. We would like to thank our industrial partners Metallo Belgium for providing us the milled raw material. We would also like to thank SCRiPTS research group, Department of Chemistry, Ghent University for helping us with the TGA measurement.

\section{REFERENCE}

Alarcon-Ruiz, L. et al. (2005) 'The use of thermal analysis in assessing the effect of temperature on a cement paste', Cement and Concrete Research. doi: 10.1016/j.cemconres.2004.06.015.

Alonso, C. and Fernandez, L. (2004) 'Dehydration and rehydration processes of cement paste exposed to high temperature environments', Journal of Materials Science. doi: 10.1023/B:JMSC.0000025827.65956.18.

Barret, P. P., Ménétrier, D. and Cottin, B. (1977) 'Study of silica-lime solution reactions', Cement and Concrete Research. doi: 10.1016/0008-8846(77)90009-6.

Benhelal, E. et al. (2013) 'Global strategies and potentials to curb CO2 emissions in cement industry', Journal of Cleaner Production. doi: 10.1016/j.jclepro.2012.10.049.

Chen, Q. Y. et al. (2007) 'Characterisation of products of tricalcium silicate hydration in the presence of heavy metals', Journal of Hazardous Materials. doi: 10.1016/j.jhazmat.2007.01.136.

Cordeiro, G. C. et al. (2008) 'Pozzolanic activity and filler effect of sugar cane bagasse ash in Portland cement and lime mortars', Cement and Concrete Composites. doi: 10.1016/j.cemconcomp.2008.01.001.

Cyr, M., Lawrence, P. and Ringot, E. (2005) 'Mineral admixtures in mortars: Quantification of the physical effects of inert materials on short-term hydration', Cement and Concrete Research. doi: 10.1016/j.cemconres.2004.05.030.

Deboucha, W. et al. (2017) 'Hydration development of mineral additives blended cement using thermogravimetric analysis (TGA): Methodology of calculating the degree of hydration', Construction and Building Materials. doi: 10.1016/j.conbuildmat.2017.04.132.

Deschner, F. et al. (2012) 'Hydration of Portland cement with high replacement by siliceous fly ash', Cement and Concrete Research. doi: 10.1016/j.cemconres.2012.06.009.

Edwin, R. S. et al. (2016) 'Effect of secondary copper slag as cementitious material in ultra-high performance mortar', Construction and Building Materials. doi: 
10.1016/j.conbuildmat.2016.05.007.

Edwin, R. S., Gruyaert, E. and De Belie, N. (2017) 'Influence of intensive vacuum mixing and heat treatment on compressive strength and microstructure of reactive powder concrete incorporating secondary copper slag as supplementary cementitious material', Construction and Building Materials. doi: 10.1016/j.conbuildmat.2017.08.036.

Grattan-Bellew, P. E. (1996) 'Microstructural investigation of deteriorated Portland cement concretes', Construction and Building Materials. doi: 10.1016/09500618(95)00066-6.

Hooton, R. D. (2000) 'Canadian use of ground granulated blast-furnace slag as a supplementary cementing material for enhanced performance of concrete', Canadian Journal of Civil Engineering. doi: 10.1139/100-014.

Juenger, M. C. G. et al. (2011) 'Advances in alternative cementitious binders', Cement and Concrete Research. doi: 10.1016/j.cemconres.2010.11.012.

Lothenbach, B., Scrivener, K. and Hooton, R. D. (2011) 'Supplementary cementitious materials', Cement and Concrete Research. doi: 10.1016/j.cemconres.2010.12.001.

Moesgaard, M. et al. (2011) 'Physical performances of blended cements containing calcium aluminosilicate glass powder and limestone', Cement and Concrete Research. doi: 10.1016/j.cemconres.2010.12.005.

Moura, W. A., Gonçalves, J. P. and Lima, M. B. L. (2007) 'Copper slag waste as a supplementary cementing material to concrete', Journal of Materials Science. doi: 10.1007/s10853-006-0997-4.

Nonnet, E., Lequeux, N. and Boch, P. (1999) 'Elastic properties of high alumina cement castables from room temperature to $1600^{\circ} \mathrm{C}$ ', Journal of the European Ceramic Society. doi: 10.1016/S0955-2219(98)00255-6.

Pane, I. and Hansen, W. (2005) 'Investigation of blended cement hydration by isothermal calorimetry and thermal analysis', Cement and Concrete Research. doi: 10.1016/j.cemconres.2004.10.027.

Piatak, N. M., Parsons, M. B. and Seal, R. R. (2015) 'Characteristics and environmental aspects of slag: A review', Applied Geochemistry. doi: 10.1016/j.apgeochem.2014.04.009.

Schlesinger, M. et al. (2011) Extractive Metallurgy of Copper, Extractive Metallurgy of Copper. doi: 10.1016/C2010-0-64841-3.

Scrivener, K. L. and Kirkpatrick, R. J. (2008) 'Innovation in use and research on cementitious material', Cement and Concrete Research. doi: 10.1016/j.cemconres.2007.09.025.

Sha, W., O’Neill, E. A. and Guo, Z. (1999) 'Differential scanning calorimetry study of ordinary Portland cement', Cement and Concrete Research. doi: 10.1016/S0008- 
8846(99)00128-3.

Siddique, R. and Klaus, J. (2009) 'Influence of metakaolin on the properties of mortar and concrete: A review', Applied Clay Science. doi: 10.1016/j.clay.2008.11.007.

Tixier, R., Devaguptapu, R. and Mobasher, B. (1997) 'The effect of copper slag on the hydration and mechanical properties of cementitious mixtures', Cement and Concrete Research. doi: 10.1016/S0008-8846(97)00166-X.

US Geological Survey \& Orienteering S, E. (2017) Mineral Commodity Summaries 2017, Government Printing Office. doi: http://dx.doi.org/10.3133/70140094.

Werner, O. R. et al. (1987) 'GROUND GRANULATED BLAST-FURNACE SLAG AS A CEMENTITIOUS CONSTITUENT IN CONCRETE.', ACI Materials Journal. doi: $10.14359 / 1623$.

Worrell, E. et al. (2001) 'CARBON DIOXIDE EMISSIONS FROM THE GLOBAL CEMENT INDUSTRY', Annual Review of Energy and the Environment. doi: 10.1146/annurev.energy.26.1.303.

Zhang, Q. and Ye, G. (2012) 'Dehydration kinetics of Portland cement paste at high temperature', in Journal of Thermal Analysis and Calorimetry. doi: 10.1007/s10973012-2303-9.

Zhou, Q. and Glasser, F. P. (2001) 'Thermal stability and decomposition mechanisms of ettringite at $<120^{\circ} \mathrm{C}^{\prime}$, Cement and Concrete Research. doi: 10.1016/S00088846(01)00558-0. 